\title{
Screening and quantification of anti- quorum sensing and antibiofilm activity of Actinomycetes isolates against food spoilage biofilm-forming bacteria
}

\author{
Erika Mulya and Diana Elizabeth Waturangi
}

\begin{abstract}
Background: Biofilms can form in many industries, one of them is the food industry. The formation of biofilms in this industry could cause immense economic losses and endanger public health. Biofilms formation is mainly triggered by quorum sensing. Therefore, inhibition of quorum sensing could be an innovative approach to inhibit the formation of biofilms. One way to inhibit quorum sensing is by using anti-quorum sensing compounds. Actinomycetes are a group of bacteria that is acknowledged to produce these compounds.

Results: There were eight crude extracts of Actinomycetes isolates that showed promising anti-quorum sensing activity against Chromobacterium violaceum. The concentration of the crude extracts was $20 \mathrm{mg} / \mathrm{mL}$. All the crude extracts showed no antibacterial activity against food spoilage bacteria, except for crude extracts of isolate 18 PM that showed antibacterial activity against Bacillus subtilis. They also showed various antibiofilm activity, both inhibition and destruction. The highest inhibition and destruction activity sequentially was done by crude extracts of isolate 12 AC with $89.60 \%$ against Bacillus cereus and crude extracts of isolate SW03 with $93.06 \%$ against Shewanella putrefaciens.

Conclusions: Actinomycetes isolates that isolated from different regions in Indonesia can be used as potential candidates to overcome biofilms formed by food spoilage bacteria using their ability to produce anti-quorum sensing compounds.
\end{abstract}

Keywords: Actinomycetes, Biofilms, Chromobacterium violaceum, Food spoilage, Quorum quenching, Quorum sensing

* Correspondence: diana.waturangi@atmajaya.ac.id

Faculty of Biotechnology, Atma Jaya Catholic University of Indonesia, Jalan Raya Cisauk-Lapan No. 10, Sampora, Cisauk, Tangerang, Banten 15345,

Indonesia

(c) The Author(s). 2021 Open Access This article is licensed under a Creative Commons Attribution 4.0 International License, which permits use, sharing, adaptation, distribution and reproduction in any medium or format, as long as you give appropriate credit to the original author(s) and the source, provide a link to the Creative Commons licence, and indicate if changes were made. The images or other third party material in this article are included in the article's Creative Commons licence, unless indicated otherwise in a credit line to the material. If material is not included in the article's Creative Commons licence and your intended use is not permitted by statutory regulation or exceeds the permitted use, you will need to obtain permission directly from the copyright holder. To view a copy of this licence, visit http://creativecommons.org/licenses/by/4.0/. The Creative Commons Public Domain Dedication waiver (http://creativecommons.org/publicdomain/zero/1.0/) applies to the data made available in this article, unless otherwise stated in a credit line to the data. 


\section{Background}

Bacteria can communicate with each other using chemical signaling molecules called autoinducers. This communication, known as quorum sensing, is orchestrated in a cell density-dependent manner. Quorum sensing can regulate several activities, such as virulence factor expression, bioluminescence, sporulation, and biofilm formation [1].

Biofilms, a group of bacteria flock together that attach to a surface and enclosed in an extracellular matrix, have significant involvement in various types of industries, one of them is the food industry. The formation of biofilms in this industry can be a firm source of contamination, which responsible for causing food to spoil, which is dangerous for the safety of the food products as well as a massive economic loss. Biofilm also making bacteria more resistant to chemical and physical treatments. Moreover, bacteria that grow as biofilms are hard to remove from the surfaces $[2,3]$. There are several bacteria such as Bacillus cereus, Bacillus subtilis, and Shewanella putrefaciens which are known for their ability to form biofilms, thus resulting in food spoilage.

Biofilms usually treated using antibiotics, but this could cause an additional problem as the long-term use of antibiotics might lead to an increase in antibiotics resistance. Furthermore, the use of antibiotics is not suitable in the food industry. Because one of the biofilms formations caused by bacteria quorum sensing, then the inhibition of quorum sensing is expected to inhibit the formation of biofilms. Every activity that inhibits the quorum sensing mechanisms recognized by the name anti-quorum sensing or quorum quenching. Actinomycetes are fungi-like Gram-positive bacteria that are well known to produce a wide range of secondary metabolites from their complex biochemical processes such as anti-quorum sensing and antibiofilm. In a previous study, it reported that Streptomyces sp. and Arthrobacter sp. crude extracts have antibiofilm activity against Streptococcus pneumoniae and Vibrio parahaemolyticus [4]. Another study showed that Streptomyces parvulus had quorum quenching activity against Chromobacterium violaceum and could inhibit biofilm formed by Pseudomonas aeruginosa, Ruegeria sp., Staphylococcus aureus, and Micrococcus luteus [5].

It is necessary to conquer the problem of food spoilage caused by biofilms in the food industry. However, research on quorum quenching and antibiofilm activity from Actinomycetes against food spoilage bacteria has not been widely explored.

The objectives of this research are to screen antiquorum sensing activity of Actinomycetes isolates against Chromobacterium violaceum as an indicator and quantify their antibiofilm activity against food spoilage biofilm-forming bacteria.

\section{Results}

Bacterial cultivation

Actinomycetes have some distinct characteristics such as calcareous-like colony, produce earthy odor called geosmin, and strongly attached to the agar medium.

\section{Screening for anti-quorum sensing activity}

A total of 30 Actinomycetes isolates successfully cultivated from cryopreservation. Eight out of 30 isolates (Table 1) used further in this research.

All eight isolates showed positive anti-quorum sensing activity against indicator bacteria Chromobacterium violaceum marked by inhibition of violacein pigment (Fig. 1).

\section{Antibacterial activity}

There were 1 out of 8 isolates (18 PM) that showed antibacterial activity against Bacillus subtilis. Positive control (Streptomycin) inhibited the growth of food spoilage bacteria (Fig. 2).

\section{Detection of anti-quorum sensing activity}

All eight crude extracts showed positive results. The inhibition performed by each extract was diverse in their activity (Table 2).

Nevertheless, all of the extracts used have quorum quenching activity against $C$. violaceum (Fig. 3), which was marked by the absence of violacein pigment around the wells.

\section{Quantification of Antibiofilm activity}

All Actinomycetes crude extracts showed both biofilm inhibition and destruction activity against B. cereus, $B$. subtilis, and $S$. putrefaciens. The inhibition activity of biofilms formed by the food spoilage bacteria can be seen in Table 3, where biofilms formed by B. cereus and S. putrefaciens inhibited the highest by crude extracts of isolate $12 \mathrm{AC}$ with inhibitory activity of 89.60 and $87.54 \%$, respectively. Crude extracts of isolate KP110 have the highest inhibitory activity against biofilms formed by $B$. subtilis with $76.43 \%$.

The destruction activity of biofilms can be observed in Table 4. Biofilms of B. cereus eradicated the highest by

Table 1 Actinomycetes isolates and their origin

\begin{tabular}{lll}
\hline No & Isolates & Origin \\
\hline 1 & 1 AC & Pantai Ancol, North Jakarta \\
2 & 12 AC & Pantai Ancol, North Jakarta \\
3 & 18 PM & Pantai Mutiara, North Jakarta \\
4 & CW02 & Cunca Wulang, West Flores (River) \\
5 & SW03 & Sawah (Paddy Field) at Gancahan 8 Village, Sleman \\
6 & SW14 & Sawah (Paddy Field) at Gancahan 8 Village, Sleman \\
7 & SW16 & Sawah (Paddy Field) at Gancahan 8 Village, Sleman \\
8 & KP110 & Kulon Progo, Yogyakarta (River) \\
\hline
\end{tabular}




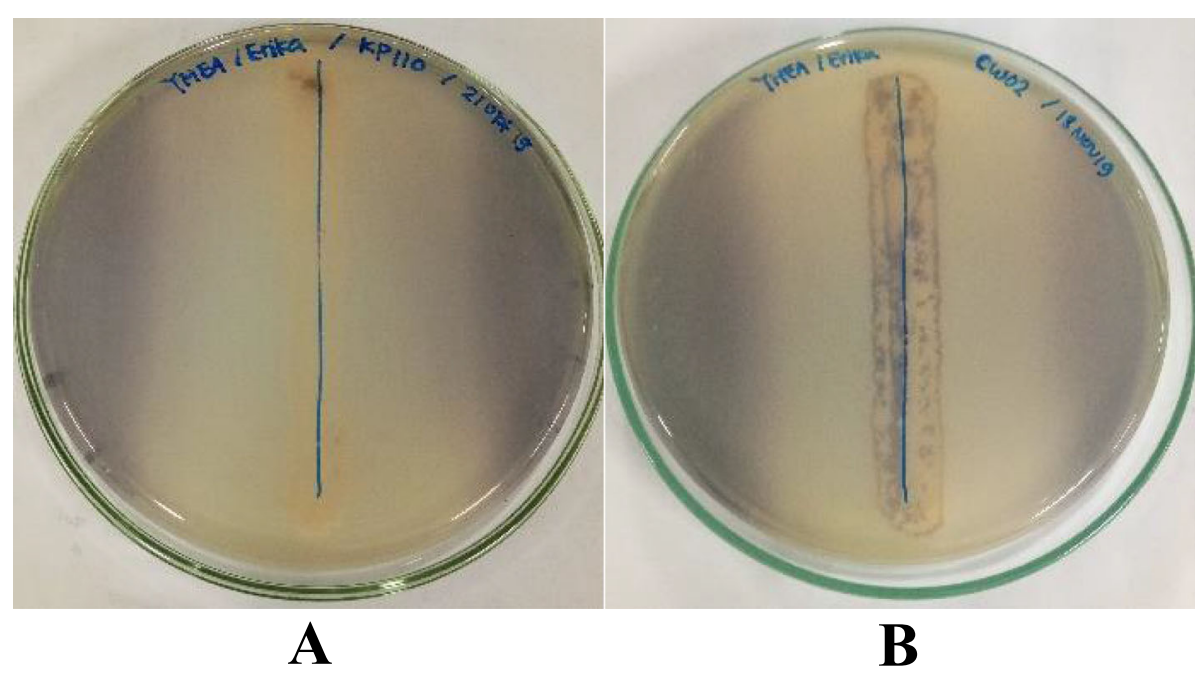

Fig. 1 Screening of anti-quorum sensing activity by (a) isolate KP110, (b) isolate CW02 against Chromobacterium violaceum

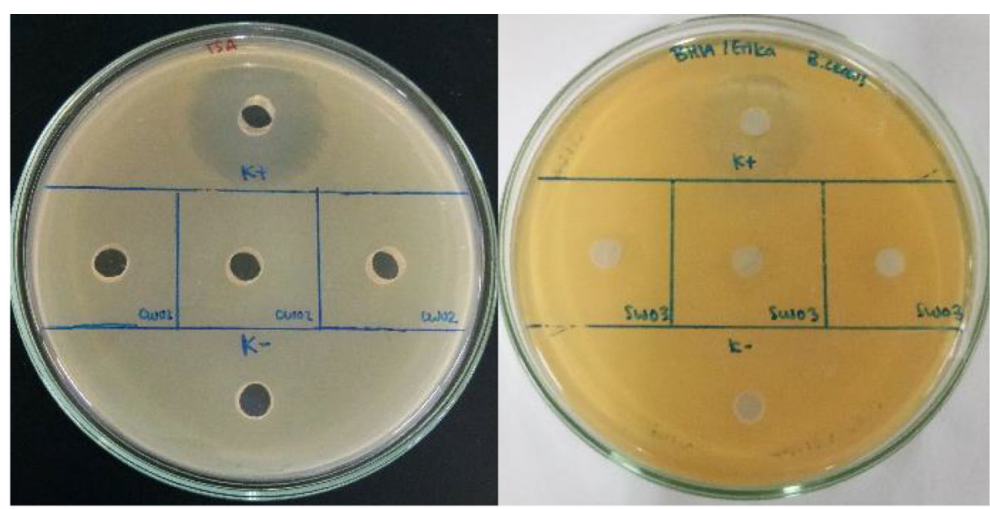

A

B

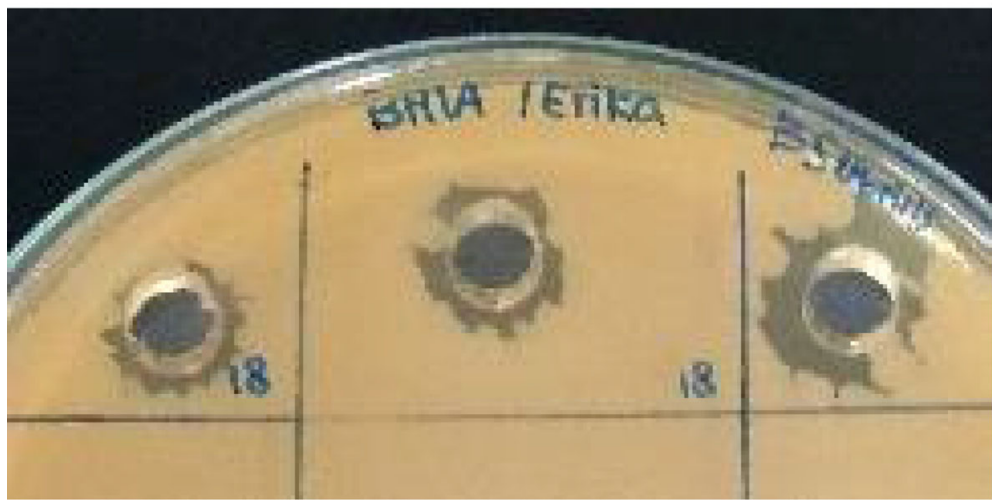

C

Fig. 2 Antibacterial activity of Actinomycetes extracts against (a) Shewanella putrefaciens, (b) Bacillus cereus, (c) Bacillus subtilis 
Table 2 Strength of anti-quorum sensing activity of Actinomycetes crude extracts against Chromobacterium violaceum

\begin{tabular}{lll}
\hline No & Isolates & Anti-Quorum Sensing Activity \\
\hline 1 & $1 \mathrm{AC}$ & ++ \\
2 & $12 \mathrm{AC}$ & +++ \\
3 & $18 \mathrm{PM}$ & +++ \\
4 & CW02 & + \\
5 & SW03 & + \\
6 & SW14 & + \\
7 & SW16 & + \\
8 & KP110 & + \\
\hline
\end{tabular}

nb: $+=$ weak inhibition, $++=$ moderate inhibition, $+++=$ high inhibition.

crude extracts of isolate $1 \mathrm{AC}$ with $75.15 \%$. The highest and lowest destruction activity of B. subtilis biofilms are sequentially 93.06 and $79.31 \%$ by crude extracts of isolate SW03 and SW16. Crude extracts of isolate $12 \mathrm{AC}$ showed the highest destruction activity against biofilms formed by S. putrefaciens with $33.49 \%$.

\section{Discussion}

Actinomycetes are widely present both in terrestrial and aquatic environments, where many other bacteria also live in this habitat. Therefore, Actinomycetes need to defend themselves in order to be able to survive and gain nutrients, for example, is by producing various secondary metabolites, such as antibiotics, antifungal, antiviral, anti-quorum sensing, and antibiofilm. Streptomycin, gentamicin, rifamycin, and erythromycin are antibiotics produced by Actinomycetes only [6].

Antibiotics can deal with biofilms formed by bacteria. However, the excessive use of antibiotics can lead to bacterial resistance towards that antibiotics. Besides, the use of antibiotics may be inappropriate in some industries. This has led to the importance of finding other ways to combat biofilm problems. Anti-quorum sensing and antibiofilm compounds from Actinomycetes can be novel to treat biofilms, specifically in this research are biofilms formed by food spoilage bacteria.

Bacillus cereus can produce extracellular proteases and lipases that could cause food degradation and food spoilage, thus resulting in a decrease in the food shelf life such as poultry, dairy, and red meat. This bacteria can also induce either emetic or diarrheal gastroenteritis [7]. Similar to $B$. cereus, a sign of $B$. subtilis infection is vomiting accompanied by diarrhea. $B$. subtilis has been reported as a producer of exoproteases and is the major cause of spoilage in bread and other cereal-based food $[8,9]$, meanwhile Shewanella putrefaciens commonly known as spoilage bacteria in seafood, poultry, and beef products that could cause abdominal tract infection and bacteremia [10].

Based on the primary screening of anti-quorum sensing activity, 8 out of 30 isolates are potential as anti-quorum sensing agents as they only inhibit the production of violacein without inhibiting the growth of Chromobacterium violaceum. Biochemical assay conducted in a previous study indicated that CW02 was Arthrobacter sp., while SW03, SW14, SW16, and KP110 were Streptomyces sp.. It also confirmed SW03 to be Streptomyces sp. with 96\% similarity and the accession number JX434849.

From the antibacterial activity assay, only one crude extract, which is $18 \mathrm{PM}$ that showed positive antibacterial against Bacillus subtilis, while the rest showed negative results. Hence, crude extracts of isolate $18 \mathrm{PM}$ will not be used further for antibiofilm activity against related pathogens. This assay was done to prevent a false-positive result. Actinomycetes are recognized as antibacterial producers that instead of inhibiting communication, inhibit the growth of bacteria [11].

Detection of anti-quorum sensing activity was carried out to ensure that all crude extracts used still have anti-

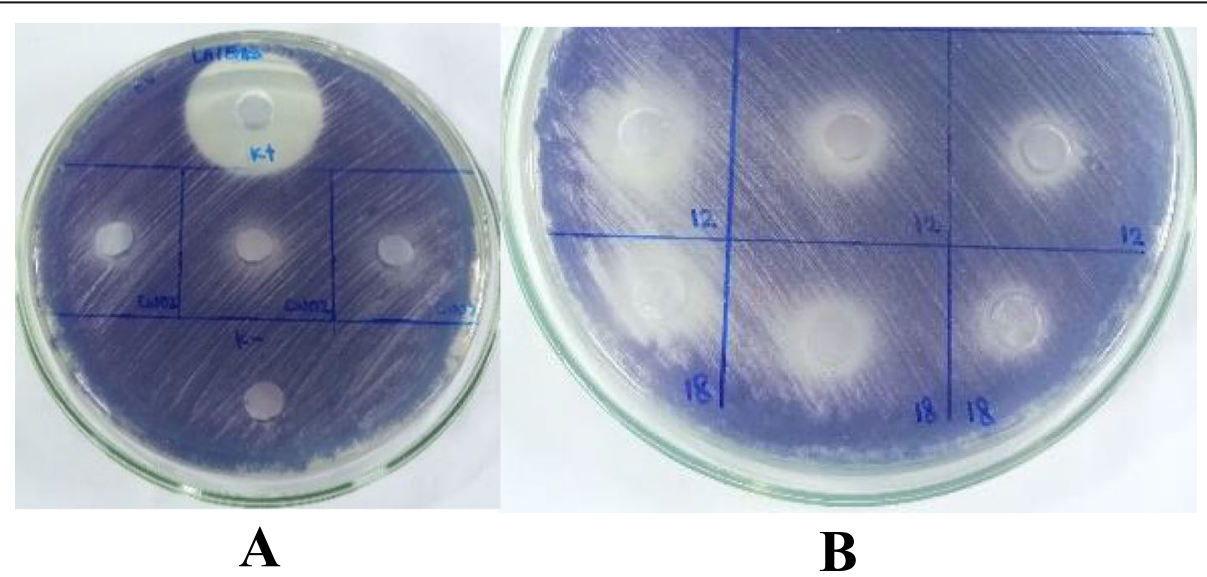

Fig. 3 Detection of anti-quorum sensing activity against Chromobacterium violaceum 
Table 3 Biofilm inhibition activity of Actinomycetes crude extracts against food spoilage biofilm-forming bacteria

\begin{tabular}{lllllllll}
\hline Pathogens & \multicolumn{1}{l}{ Inhibition (\%) } & & & & \\
\cline { 2 - 9 } & $\mathbf{1 ~ A C}$ & $\mathbf{1 2}$ AC & 18 PM & CW02 & SW03 & SW14 & SW16 & KP110 \\
\hline Bacillus cereus & 74.73 & 89.60 & 80.52 & 70.24 & 55.89 & 34.12 & 56.18 & 78.40 \\
Bacillus subtilis & 69.76 & 41.32 & $X$ & 41.74 & 54.34 & 32.98 & 52.09 & 76.43 \\
Shewanella putrefaciens & 84.50 & 87.54 & 85.09 & 24.01 & 21.70 & 55.83 & 82.56 & 24.18 \\
\hline
\end{tabular}

$\mathrm{nb}: \mathrm{X}=$ showed antibacterial activity

quorum sensing activity after extracting. The results showed that all crude extracts still have quorum quenching activity against the indicator bacteria. The signaling molecule of Gram-negative bacteria $C$. violaceum for violacein production is AHL ( $\mathrm{N}$-acyl-homoserine lactone). AHL-lactonase, AHL-acylase, paraoxonase, and oxidoreductase are enzymes that can interfere with the mechanisms of AHL quorum sensing [12]. Crude extracts in this research may have those quorum quenching enzymes that disrupt the mechanisms of violacein production. Furthermore, different crude extracts have distinct inhibitory strength, where crude extracts of isolate $12 \mathrm{AC}$ and $18 \mathrm{PM}$ showed the highest inhibition. The amount and type of quorum quenching molecules produced by each isolate may be different, which may explain the difference in inhibitory strength.

The antibiofilm activity was divided into inhibition and destruction activity. Overall, all the crude extracts have both inhibition and destruction activity. Grampositive bacteria such as Bacillus use oligopeptides as their signaling molecules. Npr, PlcR, and PapR are the quorum sensing protein in $B$. cereus that plays a role in biofilms formation [7], while in B. subtilis are ComX and CSF (Competence Sporulation Factor) peptides [13]. Gram-negative S. putrefaciens use AI-2 (Autoinducer-2) as the quorum sensing signaling molecules [14]. The biofilm inhibition activity may occur because Actinomycetes isolates produce quorum quenching compounds performed in several ways, such as disrupt the signal synthesis, degrade the signaling molecule, obstruct the signal transduction cascade, or hinder the binding of a signal molecule to the receptor [15].

Extracellular Polymeric Substance (EPS) is the major component of the biofilm matrix that responsible for the stability of biofilms that consists of polysaccharides, proteins, lipids, and nucleic acids. The EPS of B. cereus contains exopolysaccharides, proteins, and a large amount of extracellular DNA that specifically produce in biofilms [7]. B. subtilis matrix includes exopolysaccharides (glucose, galactose, fucose, glucuronic acid, and Oacetyl group) as well as proteins (TasA, TapA, and BslA) $[7,8]$. S. putrefaciens EPS majorly composed of protein and very low polysaccharide [16]. The biofilm destruction activity may ensue because the Actinomycetes crude extracts contain enzymes that have the ability to degrade EPS, such as glycosidases, proteases, and DNases [17]. A previous study [18] predicted crude extracts of isolate 1 $\mathrm{AC}$ and $18 \mathrm{PM}$ as protein or enzyme because they displayed an increase of absorbance value after Proteinase- $K$ and heat loss treatment. The varied activity of inhibition and destruction activity can also cause by assorted factors, for instance, there are still many impurities in the crude extracts, and there might be synergistic or antagonistic activity between the compounds contained in the impure crude extracts, which can increase or decrease the activities [19]. In this research, the exact bioactive compounds and the mechanisms of the crude extracts that performed the anti-quorum sensing and antibiofilm activity, as well as the genus of Actinomycetes isolates used, did not determine.

\section{Limitation}

This study screened for bioactive compounds from Actinomycetes isolates that have quorum quenching activities against Chromobacterium violaceum (AHL-based system) based on the reason that AHL is a universal signal that foster inter cell-cell communication. So we do not know whether those isolates have quorum quenching activity against different quorum sensing systems. More research using different indicator bacteria (peptide-based or AI-2-based system) should be performed to determine the exact anti-quorum sensing

Table 4 Biofilm destruction activity of Actinomycetes crude extracts against food spoilage biofilm-forming bacteria

\begin{tabular}{|c|c|c|c|c|c|c|c|c|}
\hline \multirow[t]{2}{*}{ Pathogens } & \multicolumn{8}{|c|}{ Destruction (\%) } \\
\hline & $1 \mathrm{AC}$ & $12 \mathrm{AC}$ & $18 \mathrm{PM}$ & CW02 & SW03 & SW14 & SW16 & KP110 \\
\hline Bacillus cereus & 75.15 & 52.60 & 72.54 & 35.02 & 48.85 & 71.33 & 62.13 & 61.48 \\
\hline Bacillus subtilis & 86.98 & 91.90 & $x$ & 80.70 & 93.06 & 86.36 & 79.31 & 82.49 \\
\hline Shewanella putrefaciens & 13.78 & 33.49 & 24.96 & 32.90 & 22.24 & 15.40 & 28.10 & 31.29 \\
\hline
\end{tabular}

$\mathrm{nb}: \mathrm{X}=$ showed antibacterial activity 
mechanisms owned by each isolate. We also have not done the characterization of the bioactive compounds, thereby the characterization of each bioactive compound should be carried out in the future to see if the bioactive compounds were mainly composed of proteins. Besides, this study solely provides the preliminary assay of antibiofilm activity, therefore a microscopic-based inhibition of biofilm needs to be done to ensure the biofilm inhibition ability of Actinomycetes crude extracts. Lastly, not all of our isolates have been sequenced, so molecular identification should be executed for all the Actinomycetes isolates.

\section{Conclusion}

A total of 8 Actinomycetes isolates have quorum quenching activity against $C$. violaceum as well as antibiofilm activities both inhibition and destruction against B. cereus, B. subtilis, and S. putrefaciens. Crude extracts of isolates $1 \mathrm{AC}, 12 \mathrm{AC}, \mathrm{SW} 03$, and KP110 showed promising either for biofilm inhibition and/or destruction activity. This result could contribute to the knowledge of using Actinomycetes as potential candidates to overcome biofilms formed by food spoilage bacteria by their ability as anti-quorum sensing agents. Further research is required to purify the bioactive compounds and characterizes each compound in the crude extracts and to test the crude extracts against different indicator bacteria to determine the mechanisms of the antiquorum sensing, as well as figure out the mechanisms of biofilms inhibition and destruction for further application.

\section{Methods}

\section{Bacterial cultivation}

Actinomycetes isolates used in this research were obtained from previous studies $[20,21]$ that isolated from different regions in Indonesia. That previous studies stated that a soil dilution technique using Starch Casein Agar (SCA) was performed for the isolation of Actinomycetes. Pretreatment by heated at $50{ }^{\circ} \mathrm{C}$ for $1 \mathrm{~h}$ was done for all the sediment samples. Different dilutions $\left(10^{-2}, 10^{-3}\right.$, and $\left.10^{-4}\right)$ of the marine, river, and paddy field sediment suspensions were shaken under room temperature at $200 \mathrm{rpm}$ for $1 \mathrm{~min}$, then $100 \mu \mathrm{L}$ of each suspension were spread onto SCA medium and incubated at $28^{\circ} \mathrm{C}$ for 7 days. Isolates from that previous studies were grown onto Yeast Malt Extract Agar (YMEA) (Oxoid) and incubated at $28^{\circ} \mathrm{C}$ for approximately 7 days. Indicator bacteria $C$. violaceum wild type was cultivated onto Luria-Bertani Agar (LA) (Oxoid) and incubated at $28^{\circ} \mathrm{C}$ for 2 days. Food spoilage bacteria B. cereus ATCC 10876, B. subtilis ATCC 6633 were streaked onto LA and incubated at $37{ }^{\circ} \mathrm{C} 24 \mathrm{~h}$, meanwhile S. putrefaciens ATCC 8071 was streaked onto Tryptone Soya Agar (TSA) (Oxoid) and incubated at $28^{\circ} \mathrm{C} 24 \mathrm{~h}$. All the bacteria used in this research came from Atma Jaya's culture collection.

\section{Screening for anti-quorum sensing activity}

The overlay agar method referred to Abudoleh \& Mahasneh [22] was used with modifications for this screening. Each Actinomycetes isolate inoculated onto YMEA with a straight streak method and incubated at $28^{\circ} \mathrm{C}$ for 2 days. C. violaceum was grown separately in $50 \mathrm{~mL}$ of Luria-Bertani Broth (LB) (Oxoid) and incubated at $28^{\circ} \mathrm{C} 24 \mathrm{~h}$. Indicator bacteria then diluted until $\mathrm{OD}_{600}=0.132$, then a total of $100 \mu \mathrm{L}$ culture were taken and mixed with semisolid agar (0.75\% LA) of $5 \mathrm{~mL}$ volume for an overlay on top of the selected Actinomycetes bacteria in the YMEA before, later incubated at $28^{\circ} \mathrm{C}$ for 2 days. The positive results were indicated by the absence of violacein pigmentation around the Actinomycetes isolates.

\section{Extraction of bioactive compounds}

This assay referred to Younis et al. [23] with some modifications. Each Actinomycetes isolate cultivated into 100 $\mathrm{mL}$ of Tryptone Soya Broth (TSB) (Oxoid) supplemented with $1 \%$ glucose and incubated at $28^{\circ} \mathrm{C}$ at 120 rpm for 7 days, then transferred to $50 \mathrm{~mL}$ sterile conical tubes and centrifuged at $7000 \mathrm{xg}$ for $25 \mathrm{~min}$. The cellfree supernatant was mixed with ethyl acetate (SmartLab) in a 1:1 ratio and then shaken at $120 \mathrm{rpm} 24 \mathrm{~h}$. The solvent layer was harvested and evaporated in a rotary evaporator and dried in a vacuum oven at $50^{\circ} \mathrm{C}$. The extracts then weighted, and Dimethyl Sulphoxide (DMSO) 1\% was added to achieve the final concentration of $20 \mathrm{mg} / \mathrm{mL}$, later stored at $-20^{\circ} \mathrm{C}$ for months.

\section{Antibacterial activity}

Agar well diffusion method based on the research of Tabbouche et al. [24] was used. Food spoilage bacteria $\left(\mathrm{OD}_{600}=0.132\right)$ streaked continuously in three different directions, B. cereus and B. subtilis onto the Brain Heart Infusion Agar (BHIA) (Oxoid) while S. putrefaciens onto TSA. After that, wells made using a sterile cork borer. Crude extracts of Actinomycetes $(100 \mu \mathrm{L})$ then added into the wells and incubated at $37^{\circ} \mathrm{C} 24 \mathrm{~h}$ for B. cereus and B. subtilis and $28^{\circ} \mathrm{C} 24 \mathrm{~h}$ for S. putrefaciens. Streptomycin $10 \mathrm{mg} / \mathrm{mL}$ was used as a positive control, while DMSO $1 \%$ used as a negative control. Antibacterial activity was observed through a clear zone.

\section{Detection of anti-quorum sensing activity}

Agar well diffusion method referred to Rajivgandhi et al. [25] was used with some modifications. C. violaceum $\left(\mathrm{OD}_{600}=0.132\right)$ streaked continuously in three different directions onto the LA. Wells were made using a sterile cork borer. The Actinomycetes crude extracts $(100 \mu \mathrm{L})$ 
then added into the wells and incubated at $28^{\circ} \mathrm{C} 24 \mathrm{~h}$. Streptomycin $10 \mathrm{mg} / \mathrm{mL}$ was used as a positive control, while DMSO 1\% used as a negative control. Quorum quenching activity was observed through the inhibition of violacein production around the wells.

\section{Quantification of Antibiofilm activity}

The quantification of antibiofilm activity was based on the research by Waturangi et al. [4] with some modifications. The activities of antibiofilm were divided into inhibition and destruction activity. For inhibition activity, B. cereus and B. subtilis inoculated into Brain Heart Infusion Broth (BHIB) and incubated at $37^{\circ} \mathrm{C}, 120 \mathrm{rpm} 24$ $\mathrm{h}$, whereas S. putrefaciens inoculated into BHIB and incubated at $28^{\circ} \mathrm{C}, 120 \mathrm{rpm} 24 \mathrm{~h}$. A total of $100 \mu \mathrm{L}$ cultures $\left(\mathrm{OD}_{600}=0.132\right)$ and $100 \mu \mathrm{L}$ crude extract were transferred into a 96-wells microplate and incubated at $37^{\circ} \mathrm{C} 24 \mathrm{~h}$ for B. cereus and B. subtilis and $28^{\circ} \mathrm{C}$ for $S$. putrefaciens. For destruction activity, a total of $100 \mu \mathrm{L}$ cultures $\left(\mathrm{OD}_{600}=0.132\right)$ were transferred into a 96-wells microplate and incubated to form biofilms. After $24 \mathrm{~h}$, $100 \mu \mathrm{L}$ crude extract was added to each well then reincubated. Overnight culture of food spoilage bacteria without any treatment were used as a positive control, while sterile BHIB was used as a negative control.

After incubation, the planktonic cells and media were discarded and the adherent cells were rinsed twice with deionized water and allowed to air dry. A total of $200 \mu \mathrm{L}$ of $0.4 \%$ crystal violet was used to stain the adherent cells for $30 \mathrm{~min}$. Thereafter, the dye was discarded and the wells were rinsed five times with deionized water and allowed to air dry. Afterward, $200 \mu \mathrm{L}$ of ethanol was added to solubilize the crystal violet. The optical density was determined at $595 \mathrm{~nm}$ with a microplate reader (TECAN M200 PRO). The percentage of inhibition or destruction activity calculated using the following equation:

$$
\% \text { inhibition or destruction }=\frac{\text { OD positive control }- \text { OD sample }}{\text { OD positive control }} \times 100 \%
$$

\footnotetext{
Acknowledgements

The authors acknowledge research funding support by the Indonesian Ministry of Education and Culture through competitive national research grant 2019-Fundamental Research.
}

\section{Authors' contributions}

EM: conduct research, data analysis, manuscript preparation under the advisory of DEW. DEW: personal investigator, design proposal, and advisory the research. All authors read and approved the final manuscript.

\section{Funding}

This study was funded by DIKTI 2019. The funder has no contribution in design, collection, writing, and interpreting data in this study.

\section{Availability of data and materials}

The datasets used and/or analyzed during the current study are available from the corresponding author on reasonable request.
Ethics approval and consent to participate

Not applicable.

\section{Consent for publication}

Not applicable.

\section{Competing interests}

The authors declare that they have no competing interests.

Received: 4 August 2020 Accepted: 2 December 2020

Published online: 02 January 2021

\section{References}

1. Nazzaro F, Fratianni F, Coppola R. Quorum sensing and phytochemicals. Int J Mol Sci. 2013;14(6):12607. https://doi.org/10.3390/ijms140612607.

2. Houdt RV, Michiels CW. Biofilm formation and the food industry, a focus on the bacterial outer surface. J Appl Microbiol. 2010;109(4):1117. https://doi. org/10.1111/j.1365-2672.2010.04756.x.

3. Kerekes EB, Deák E, Takó M, Tserennadmid R, Petkovits T, Vágvölgyi C, et al. Anti-biofilm forming and anti-quorum sensing activity of selected essential oils and their main component on food-related micro-organisms. J Appl Microbiol. 2013;115(4):933. https://doi.org/10.1111/jam.12289.

4. Waturangi DE, Rahayu BS, Lalu KY, Michael MN. Characterization of bioactive compound from actinomycetes for antibiofilm activity against gramnegative and gram-positive bacteria. Malays J Microbiol. 2016;12(4):291. https://doi.org/10.21161/mjm.80915.

5. Miao L, Xu J, Yao Z, Jiang Y, Zhou H, Jiang W, et al. The anti-quorum sensing activity and bioactive substance of a marine derived Streptomyces. Biotechnol Biotechnol Equip. 2017;31(5):1007. https://doi.org/10.1080/ 13102818.2017 .1348253$.

6. Bhatti AA, Haq S, Bhat RA. Actinomycetes benefaction role in soil and plant health. Microb Pathog. 2017;111:458. https://doi.org/10.1016/j.micpath.2017. 09.036.

7. Majed R, Faille C, Kallassy M, Gohar M. Bacillus cereus biofilms - same, only different. Front Microbiol. 2016;7:1054. https://doi.org/10.3389/fmicb.2016. 01054.

8. Marvasi M, Visscher PT, Martinez LC. Exopolymeric substances (EPS) from Bacillus subtilis: polymers and genes encoding their synthesis. FEMS Microbiol Lett. 2010;313(1):1. https://doi.org/10.1111/j.1574-6968. 2010.02085.x.

9. Logan NA. Bacillus and relatives in foodborne illness. J Appl Microbiol. 2011; 112(3):417. https://doi.org/10.1111/j.1365-2672.2011.05204.x.

10. Paździor E. Shewanella putrefaciens - a new opportunistic pathogen of freshwater fish. J Vet Res. 2016;60(4):429. https://doi.org/10.1515/jvetres2016-0064.

11. Rahman MA, Islam MZ, Islam MAU. Antibacterial activities of actinomycetes isolates collected from soils of Rajshahi, Bangladesh. Biotechnol Res Int. 2011;2011:1. https://doi.org/10.4061/2011/857925.

12. Chen F, Gao Y, Chen X, Yu Z, Li X. Quorum quenching enzymes and their application in degrading signal molecules to block quorum sensingdependent infection. Int J Mol Sci. 2013;14(9):17477. https://doi.org/10.3390/ ijms140917477.

13. Shank EA, Kolter R. Extracellular signaling and multicellularity in Bacillus subtilis. Curr Opin Microbiol. 2011;14(6):741. https://doi.org/10.1016/j.mib. 2011.09.016

14. Zhu S, Wu H, Zeng M, Zunying L, Zhao Y, Dong S. Regulation of spoilagerelated activities of Shewanella putrefaciens and Shewanella baltica by an autoinducer-2 analogue, (z)-5-(bromomethylene)furan-2(5h)-one. J Food Process Preserv. 2014;39(6):719. https://doi.org/10.1111/jfpp.12281.

15. Brackman G, Coenye T. Quorum sensing inhibitors as anti-biofilm agents. Curr Pharm Des. 2015;21(1):5-17.

16. Castro L, Blázquez ML, González F, Muñoz JA, Ballester A. Anaerobic bioleaching of jarosites by Shewanella putrefaciens, influence of chelators and biofilm formation. Hydrometallurgy. 2017;168:56. https://doi.org/10. 1016/j.hydromet.2016.08.002

17. Blackledge MS, Worthington RJ, Melander C. Biologically inspired strategies for combating bacterial biofilms. Curr Opin Pharmacol. 2013;13(5):699. https://doi.org/10.1016/j.coph.2013.07.004.

18. Wijaya M, Delicia D, Waturangi DE. Screening and quantification of antiquorum-sensing activity of Actinobacteria isolates against gram-positive 
and gram-negative biofilm associated bacteria. Res Square. 2020. https://doi. org/10.21203/rs.2.24412/v1.

19. Omran R, Kadhem MF. Production, purification, and characterization of bioactive metabolites produced from rare actinobacteria Pseudonocardia alni. Asian J Pharm Clin Res. 2016;9(3):1. https://doi.org/10.22159/ajpcr.2016. v9i2.14961.

20. Andreas. Screening of actinomycetes from marine sediments to inhibit Vibrio cholerae biofilm formation. Biotechnology, Honours [thesis]. Jakarta: Atma Jaya Catholic University of Indonesia; 2011.

21. Vidyawan V. Screening of actinomycetes from various environment sediments to inhibit biofilm formation of Vibrio cholerae. Biotechnology, Honours [thesis]. Jakarta: Atma Jaya Catholic University of Indonesia; 2012.

22. Abudoleh SM, Mahasneh AM. Anti-quorum sensing activity of substances isolated from wild berry associated bacteria. Avicenna J Med Biotech. 2017; 9(1):23-30.

23. Younis KM, Usup G, Ahmad A. Secondary metabolites produced by marine Streptomyces as antibiofilm and quorum-sensing inhibitor of uropathogen Proteus mirabilis. Environ Sci Pollut Res. 2015;23(5):4756. https://doi.org/10. 1007/s11356-015-5687-9.

24. Tabbouche SA, Gürgen A, Yildiz S, Kilic AO, Sökmen M. Antimicrobial and anti-quorum sensing activity of some wild mushrooms collected from Turkey. MSU J Sci. 2017;5(2):453. https://doi.org/10.18586/msufbd.347692.

25. Rajivgandhi G, Vijayan R, Maruthupandy M, Vaseeharan B, Manoharan N. Antibiofilm effect of Nocardiopsis sp. GRG 1 (KT235640) compound against biofilm forming gram negative bacteria on UTIs. Microb Pathog. 2018;118: 190. https://doi.org/10.1016/j.micpath.2018.03.011.

\section{Publisher's Note}

Springer Nature remains neutral with regard to jurisdictional claims in published maps and institutional affiliations.

Ready to submit your research? Choose BMC and benefit from:

- fast, convenient online submission

- thorough peer review by experienced researchers in your field

- rapid publication on acceptance

- support for research data, including large and complex data types

- gold Open Access which fosters wider collaboration and increased citations

- maximum visibility for your research: over $100 \mathrm{M}$ website views per year

At $\mathrm{BMC}$, research is always in progress.

Learn more biomedcentral.com/submissions 